\title{
ESP Students' Recount Text from SFL Perspective: Pedagogical Implication Based on Students' Writing Analysis
}

\author{
Canda Putri Anggini, Eri Kurniawan \\ Universitas Pendidikan Indonesia \\ candaanggini15@gmail.com, erikurn@upi.edu
}

\begin{abstract}
Many students are committing mistake in writing by showing some errors in written product. The existing approach to teach ESP writing applied by the teachers is still using traditional grammar. Systemic Functional Linguistics offer a new perspective in analysing students' text which focuses on meaning and function behind the language. The study analysed students' recount texts which are purposively chosen as it used qualitative case study design. The result of the study showed that students already understand the social function of recount text, most students are not aware of writing re-orientation in the text, the other problem is that students mostly misuses past tense in recount text, the last problem faced by students is in interpersonal meta-function. The students have problem in constructing the Mood of the sentence because they miss the finite or the subject. Since the problem encountered by students need to be solved, a strategy known as POWER was proposed to help students in overcoming the problems.
\end{abstract}

Keywords: POWER strategy, recount text, systemic functional linguistics

\section{INTRODUCTION}

In university level, where ESP is taught, students face difficulty as they reach college. Most students do not enroll to college with adequate ability to write properly (Greene \& Foster, 2003). In addition, the writing instruction is not applied correctly or it is not used at all which cause the writing difficulties. The sign of difficulties in students' written product can be seen from students' errors in their written product. Dewi and Kurniawan (2018) revealed that students made errors in grammar use. Students made mistakes in using preposition, noun, adjective clause, comparison, pronoun, infinitive, adverb of time, and passive voice. In addition, Fauziati (2011) also concluded that students made distinctive grammatical errors in terms of verb, to be, morpheme, syntactic structure, noun, preposition, pronoun, and article. Another study done by Henry and Roseberry (2007) found out that the majority of errors produced by students were errors of usage, and that there was a relationship between the types of errors and the move-strategy employed.

Recount text is a familiar genre to students since they are exposed to this text from junior high school and it is considered as an easy genre to make because they write their real-life experience. According to Nafisah and Kurniawan (2007), recount text enables students to write a sequence of events which they already acquired in the past. The events are written on chronological order. Therefore, they are marked by time and developed based on the events. Gerot and Wignell (1995) convey that the purpose of writing recount text is intended to entertain or inform readers about what happened and when it happened in the past. The form of recount text can be varied among the students. According to Anderson and Anderson (2003), recount text can be in the form of diaries, letter, biographies, and speeches. Recount text can be distinguished from the other genre since they consist of orientation, records of events, and reorientation (Anderson \& Anderson, 2003).

According to Halliday and Matthiessen (2014) text is a many-faceted phenomenon which has meaning in different ways. They also argued that text has two main angles, namely as an object and as an instrument for finding something else. In systemic functional linguistic, a text can be analysed from the social function, linguistic features, and the schematic structure. In recount text, it is considered as a text from the SFL perspective since it has social function, linguistic features and schematic structure which then can be analysed by employing the three language metafunctions in SFL specifically interpersonal metafunction, experiential metafunction, and textual metafunction.

To describe the experiential function, some terms are employed to divide the sentence into three constituents, namely participants, process, and circumstances according to Butt, Fahey, Feez, Spinks, and Yallop (2000). A participant can be a person, a place or an object, which commonly marked by nominal group which can have pre modification and post modification. The processes in sentence is marked by verbal group. The event in verbal group may stand alone or be preceded by other words in group. Recount text is assembled by sequence of events which deals with action.

There are five process which might appear in recount text namely material, mental, behavioural, verbal, and existential. In recount text, the most common process appear are material process (Gerrot \& Wignell, 2014). The material process is related to what someone did or what happened. In recount text, the material process is noted by action verb and the participant has actor role. The action verb in recount text is expressed in past verb. Even though material process generally appears in recount text, the other processes might appear as well. In mental process, the writer tries to construe what they think or feel upon the action process. In recount text, mental process is expressed by showing the feeling upon the events. The third process, behavioural, is expressed in recount text by showing physiological or 
psychological behaviour. The fourth process is verbal process which tries to convey saying. In recount text, verbal process is expressed because the writer wants to cite, quote or say something. The next process is existential process. This process intended to construe being as simple existence. In recount text, existential process is usually used to portray the setting of the events. The last process is relational process. This process is intended to relate the participant to the identity or description. Similar with existential process, relational process can be used to describe the person involved in the event, or the things existed in the events.

The last constituent is circumstances. They are any piece of circumstantial information about process within its own clause. Circumstances try to tell the audience about where, when, how, why, with whom, or as what the process occurs. In recount text, the circumstances can be filled with the adverbial phrase or prepositional phrases.

In a general, the previous studies (e. g. Cakrawati, 2018; Sayukti \& Kurniawan, 2018) attempted to analyse ESP students recount text by employing Systemic Functional Linguistic principles. The features of recount text are analysed based on Gerot and Wignell (1995) principles of recount text.

\section{METHOD}

This study was intended to analyse students recount text from SFL perspective. The research method adopted was case study. Yin (2003) stated that case study is a kind of research method which allows investigation to retain the holistic and meaningful characteristics of real-life events. In addition, Hamied (2017) conveyed that case study is an appropriate method to analyse explanatory questions of social phenomenon. The data were collected from four students' recount text to represent the phenomena during the ESP writing class. The students' texts were chosen from four second semester students of a private university in Malang majoring in Accounting. The consideration in choosing only four text is that the four texts represent the common problems faced by students in writing class. The researcher analysed all the students' text and the findings were already saturated. Therefore, the four texts represented all the mistakes students commit in a writing. The data from the text then analysed by using content and error analysis. The content analysis was based on the three metafunctions in SFL. Therefore, the texts were break down into sentences. Then, every sentence was analysed using the three metafucntions. This analysis was intended to see students' error in every metafunction. Besides that, a comprehensive analysis was also done related to the features of recount text. An interview was also conducted to the teacher of ESP writing. The interview was intended to explore students' problems in writing recount text. The teachers were asked about the common problems students face in writing as the teacher check the students product and following the students' writing process in class.

\section{FINDINGS AND DISCUSSION}

This section discusses the findings related to students' text analysis. The findings are divided into two section; (1) students' recount text feature analysis, and (2) students' recount text analysis in SFL context.

\section{A. Students' recount texts feature analysis}

Define abbreviations and acronyms the first time they are used in the text, even after they have been defined in the abstract. Abbreviations such as IEEE, SI, MKS, CGS, sc, dc, and rms do not have to be defined. Do not use abbreviations in the title or heads unless they are unavoidable.

\section{Social Function}

Basically, the social function of recount text is to tell the past experience. Gerot and Wignell (1995) conveyed that the purpose of writing recount text is intended to entertain or inform readers about what happened and when it happened in the past. The social function of the text can be achieved by providing sequences of events or an event in the past. In terms of social function, it can be concluded that the students' writings have told about the past experiences. It can be seen from the students' writings which expressed their experiences that day and they also highlight what was the most important activity they had that day. Personal recount which the students wrote contained some activities or an activity which they already did indicating that they already reached the social function of recount text.

\section{Generic Structure}

The generic structure of recount text consists of orientation, chronological event(s), and reorientation. In orientation stage, writer should state the person involved, where and when the experiences took place. The next stage is chronological events where students should write about the things happened in chronological sequences. The last stage should include the closure and comment of the events. In terms of generic structure, most of the students' writing already showed the orientation and the chronological events. They stated the orientation in the first sentence. The rest of the sentences in the stories indicated the chronological events. However, most of the students miss the last part, which is reorientation. This is caused by the fact that reorientation is not a must in writing a recount text. On the other hand, students may skip to write it since it is not compulsory. In addition, the students' ideas in chronological events are not well organized since they rarely used conjunction to connect the sentences. Their ideas are separated even though they are supporting each other. The example of text analysis is presented in Table I. 
TABLE I. The Generic Structure of Students' ReCOUnt TeXts

\begin{tabular}{|l}
\hline Orientation \\
(1) Yesterday I listened to my friend \\
(2) Who finished doing SNMPTN test \\
(3) Actually I want to take the test \\
(4) But I do not think there is any preparation \\
\hline Events \\
(5) When I heard my friend tell me \\
(6) It turns out that the landfill is more difficult \\
(7) But when I think \\
(8) Maybe she is less prepared
\end{tabular}

3. Linguistic Features

There are several aspects of linguistic features or the lexicogrammar of the text. According to Gerot and Wignell (1995), there are several lexicogrammatical features of recount namely focus on specific participants, use of Material Processes, circumstances of time and place, use of past tense, and focus on temporal sequences. From the analysis of the students' text, it can be inferred that students already applied almost all the lexicogrammatical features of a recount text. First, the students' focus participant was clear. Students used the word "I" since the text they wrote was personal recount. Second, most of the sentences in students' written text is in the form of material process and relational process. However, students use mix tenses which is dominated by the use of present tense that indicate students cannot differentiate the function of different tenses, especially in textual context. They use present, past, and future tense in writing, while they need to use only past tense. Fourth, in terms of temporal sequences, most students only told an event. Therefore, the students' writing is not rich of ideas.

\section{B. Students' recount text analysis in SFL context}

\section{Interpersonal Metafunction}

Interpersonal metafunction is related with the relationship between the speaker and the hearer. As stated by Thompson (2004) there would be contexts such as the relationship between speaker and hearer that affect the choice of sentence/wordings. We might use different form in speaking to others depending on the relationship we have. The relationship can be expressed by the use of Mood. From the Mood system, the common Mood of the sentences in the text are declarative Mood. This is logic that students used declarative Mood since they wrote recount text which have to be informative. The declarative Mood is constructed by the use of Subject and Finite. The total clauses that students produced in the texts are 22 sentences with 42 clauses which then categorized into 35 positive declarative clauses and seven negative declarative clauses. The followings are examples of students' positive and negative declarative clauses.

Clause 4: because there are many brothers. (positive declarative clause)

$\checkmark$ Clause 20: so, I do not lose. (negative declarative clause)
Based on the text analysis, it can be claimed that the students wrote declarative Mood with subject followed by finite with some time adjuncts preceding or following. However, not all clauses are having subject and finite. In some cases, the students did not write the finite or the subject which indicate the students' misunderstanding in constructing sentence. The example of student's error in constructing Mood is presented below:

Clause 3: so what I do just saving my energy. (no finite)

Clause 19: so do not understand the problem. (no subject)

Clause 28: and still not familiar with fasting. (no subject and finite)

From the examples above, we can indicate that the students miss the finite in constructing sentences which means that students cannot construct proper sentences. Finite is an important element in constructing the Mood since it expresses the thought of the speaker.

Concerning the modality used in texts, there are some analysis result. First, in expressing certainty, student use the word can as in I can go back and will as in I will meet my high school friend. However, the second use of certainty is not proper as they need to use past tense. Second, in expressing usuality, student use the word sometimes as in sometimes I'm off. There is rarely the use of modality expressed by the students which indicated that they concern less on giving judgement and attitudes towards certain thing.

2. Experiential Metafunction

To describe the experiential function, three constituents are used namely participants, process, and circumstances according to Butt et al. (2000). In writing recount text, the common process occur in a clause is material process. As mentioned by Gerot and Wignell (1995) one lexicogrammatical feature of recount text is the material process. It is proven from the result of the analysis which indicated that students used material, relational, and mental processes.

In composing the recount text, the students employed material and relational process to begin the paragraph. As in orientation, students need to state the setting and also the participant of the story by using material and relational processes. For example, the students wrote $I$ break the fast at your house. This clause is using material process which function is to construe doing or happening. By using material process, students express the setting and participant of the story. Other student used relational process to begin the paragraph. Relational process is used to construe being. In the text written by the students for example, today I am very happy is used to express the feeling toward the action happened that day. The relational process is used to introduce the material process following the clause. Besides material and relational, there is also mental 
process found in students writing. This process accommodates the students to express their feeling since they wrote personal recount which involves themselves as the main actor. Other clauses have a mental process and existential process, but the amount is not as much as mental and relational process. Below is the examples from students' text.

$\begin{array}{ccccc} & \text { Yesterday } & \text { I } & \text { listened to } & \text { my friend } \\ \text { Exp } & \text { Circumstance } & \text { Actor } & \text { Process Material } & \text { Goal } \\ & \text { Maybe } & \text { She } & \text { is } & \text { less prepared } \\ \text { Exp } & \text { Circumstance } & \text { Carrier } & \text { Process Relational } & \text { Attribute }\end{array}$

Although there are some errors in using the tenses, students already showed that they understand the social function of recount text. Students' use of material and relational process imply the activities done in the past.

\section{Textual Metafunction}

Textual metafunction is an analysis which used the theme and rheme of text to construe the cohesion and coherence of text. Theme deals with the first constituent which the clause is composed from. Rheme, on the other hand, is developed by picking up what has been mentioned or delivered previously by adding more information that is not mentioned before (Butt et al, 2000; Thompson, 2014).

The students are asked to write personal recount which topic in every student's text is rarely similar. The students wrote about their activity on that day but they can have different activities. In this student's writing, the writer chooses to employ textual theme. It can be indicated from the students' text that they use some conjunction to show the "linking function" in the text.

All students' text is conveying their activities. Therefore, all students focus the subject by using "I". However, the subject of the sentence is changing through the text. The theme of the text is different in every sentence and there is no pronoun can be seen.

It can be seen that the text is not cohesive since the theme is changing through the text. However, the writer used some conjunction to show the textual theme in the text. Conjunction is employed to give the reader the texture of the text. Most of the conjunction used in the text is because and but which indicated that students are not really familiar with the other conjunction. Most of the sentences employed by students are complex sentence which shows that students already have the capability to construct complex sentences.

The text does not have a certain pattern since the sentences are not connected each other. The students present the ideas separately in every sentence. In addition, the students' writing product does not show thematic reiteration since the theme in every sentence is different. Therefore, the topic is not focus and cohesive.

Students' ability in writing recount text can be identified from the errors they committed in writing. In generic structure, most errors were missing reorientation part in writing. This finding is supported by other study conducted by Ramli (2013) which found out that the majority of the mistake students committed were in reorientation part which has 37 errors. Moreover, students have problems in organizing the ideas in recount text. This is caused by the missing connectors between sentences. Cakrawati (2018) analyzed senior high school students recount text and found out that the students did not write the events in well-sequenced manner since the connector was missing and the writer also did not provide the reorientation part as the closure of recount text.

In terms of tenses use, students did mistake in using tenses for writing recount text by using present tense in writing. This mistake can be caused by students' shallow understanding on the use of different tenses in writing different genre. Students made 57 errors in writing recount text by using present tense instead of past tense, such as using present verbs in writing recount (Agustina, 2016)

Students' recount texts were analyzed by using SFL norms. The first thing that should be noticed from students' recount text was the missing of finite in their interpersonal function. Most students did not provide the finite in the clauses. The main problem that Indonesian students face in interpersonal metafunction is the matter of finiteness, in which students miss the use of "have" in the sentence (Dewi \& Kurniawan, 2018). Second, in experiential metafunction, students tend to employ material and relational process. A study conducted by Dewi and Kurniawan (2018) also found out that vocational high school students applied material process in writing their recount text which indicated that students has fulfilled one of recount text criteria. In addition, Cakrawati (2018) also stated that the majority of senior high school students recount text use material process. Gerot and Wignell (1995) emphasised one of the recount texts features which is the use of material process in writing. Third, in textual metafunction, students recount texts were not cohesive and did not follow a certain pattern or do not have thematic progression. Another study conducted by Cakrawati (2018) revealed that the repetition which keep readers focus on the main idea was hardly found in the text indicating that the theme progression was not developed well. This also affected on the lack of coherence and cohesion.

Considering students' problem in writing recount text, there is a need of implementing writing strategy to help students overcome the difficulties. Choosing an appropriate strategy to be implemented is a challenge for the teachers. There are some considerations in choosing the right strategy for the students. First, teachers need to scrutinize the students' characteristic. ESP students are different from university students majoring in English. They do not get exposure as many as the students from English department. In addition, the subjects are also having motivation problem in learning English. Moreover, the students need strategy which can help them to do the task individually as well as in a group to foster independent learning. Second, students have problems in constructing recount text in sentence level. Therefore, the strategy should emphasize the sentence construction. Third, students' compositions are not written following the generic structure of recount text. Accordingly, they need modelling of recount text before writing. Fourth, the time allotment for writing recount is only two meetings. 
Therefore, the strategy needs to be concise and clear for the students.

\section{CONCLUSION}

Based on the analysis of the sample texts, there are some conclusions that can be drawn. First, in term of social function, the students already showed the social function of recount text through their writing. Second, the generic structure of the students' texts already showed the stages which is orientation and events but most students did not state the reorientation. Third, in term of lexicogrammatical feature, the students' text indicated that students have problems in using past tense. It is proven from the text which mostly use present tense to show the events. Lastly, the challenge in metafunction that encountered by students is shown mostly in interpersonal metafunction. The students have problem in constructing the Mood of the sentence because they miss the finite or the subject. However, the Mood choice indicating declarative Mood is already appropriate for recount text. In experiential metafunction, students mostly use material and relational process. Moreover, in textual metafunction students have problem in maintaining the thematic progression and zigzag pattern.

\section{REFERENCES}

Agustina, T. (2016). Error analysis in writing recount text. Journal of Literature, Linguistics, and Language Teaching, 3(1). 81-89.

Butt, D., Fahey, R., Feez, S., Spinks, S., \& Yallop, C. (2000). Using functional Grammar: An explorer's guide. Sydney NSW: National Centre for English Language Teaching and Research.

Cakrawati, L. M. (2018). Recount text in SFL perspective: Pedagogical implication based on student's writing analysis. Register Journal, 11(2). 192-209. doi: 10.18326/rgt.v11i2.210-227
Dewi, R. K. S., \& Kurniawan, E. (2018). Seeing recount from systemic functional linguistic perspective: Sine qua non attributes. RETORIKA: Jurnal Ilmu Bahasa. 4(1). 43-52. doi: 10.22225/jr.4.1.464.43-52

Fauziati, E. (2011). Interlanguage and error fossilization: A study of Indonesian students learning English as a foreign language. Indonesian Journal of Applied Linguistics, 1(1), 23-38.

Gerot, L., \& Wignell, P. (1995). Making Sense of Functional Grammar: An Introductory Workbook. Australia: Gerd Stabler.

Greene, J., \& Forster, G. (2003). Public high school graduation and college readiness rates in the United States. Education Working Paper 3. New York: Manhattan Institute for Policy Research.

Halliday, M. A. K., \& Matthiessen, C. M. I. M. (2014). Halliday's introduction to functional grammar $\left(4^{\text {th }} \mathrm{Edn}\right.$.). London: Routledge.

Hamied, F. A. (2017). Research Methods: A Guide for First-Time Researcher. Bandung: UPI Press.

Henry, A., \& Roseberry, R. L. (2007). Language errors in the genre-based writing of advanced academic ESL students. RELC Journal. 38(2), 171198. doi: $10.1177 / 0033688207079692$

Nafisah, N., \& Kurniawan, E. (2007). Writing English for General Communication. Bandung: UPI PRESS

Ramli, D. (2013). An Analysis on Students' Error in Writing Recount Text. Jurnal Pendidikan dan Pembelajaran Khatulistiwa, 2(2).

Sayukti, N. K. H., \& Kurniawan, E. (2018). An analysis of student's recount text in systemic functional linguistic perspectives. RETORIKA: Jurnal Ilmu Bahasa, 4(1). 53-59. doi: 10.22225/jr.4.1.466.53-59

Thompson, G. (2004). Introduction to functional grammar ( $2^{\text {nd }}$ Edn.). London: Arnold Publishers.

Thompson, G. (2014). Introducing functional grammar ( $3^{\text {rd }}$ Edn.). New York: Routledge.

Yin, R. K. (2003). Case study approach: design and method ( $3^{\text {rd }}$ Edn.). California: SAGE 